\title{
Regulation of $\operatorname{clp} Q^{+} Y^{+}\left(h s l V^{+} U^{+}\right)$Gene Expression in Escherichia coli
}

\author{
Hsiang-Yun Lien ${ }^{1}$, Chien-Hung $\mathrm{Yu}^{1}$, Chung-Ming Liou $^{2}$ and Whi Fin $\mathrm{Wu}^{1,2, *}$ \\ ${ }^{I}$ Department of Agricultural Chemistry, National Taiwan University, Taipei (106), Taiwan, R.O.C \\ ${ }^{2}$ Department of Biochemical Science and Technology, Institute of Microbiology and Biochemistry
}

\begin{abstract}
The Escherichia coli ClpYQ (HslUV) complex is an ATP-dependent protease, and the $c l p Q^{+} Y^{+}\left(h s l V^{+} U^{+}\right)$operon encodes two heat shock proteins, ClpQ and ClpY, respectively. The transcriptional (op) or translational (pr) $c l p Q^{+}: \because l a c Z$ fusion gene was constructed, with the $c l p Q^{+} Y^{+}$promoter fused to a $l a c Z$ reporter gene. The $c l p Q^{+}:: l a c Z$ (op or pr) fusion gene was each crossed into lambda phage. The $\lambda \operatorname{clp} Q^{+}: \because l a c Z^{+}$(op), a transcriptional fusion gene, was used to form lysogens in the wild-type, $r p o H$ or/and $r p o S$ mutants. Upon shifting the temperature up from $30{ }^{\circ} \mathrm{C}$ to $42{ }^{\circ} \mathrm{C}$, the wild-type $\lambda \operatorname{clp} Q^{+}: \because$ lac $^{+}$(op) demonstrates an increased $\beta$-galactosidase ( $\beta \mathrm{Gal}$ ) activity. However, the $\beta \mathrm{Gal}$ activity of $c l p Q^{+}: \because l a c Z^{+}$(op) was decreased in the $r p o H$ and $r p o H$ rpoS mutants but not in the rpoS mutant. The levels of $\operatorname{clp} Q^{+}:: l a c Z^{+}$mRNA transcripts correlated well to their $\beta$ Gal activity. Similarly, the expression of the $\operatorname{clp} Q^{+}:: l a c Z^{+}$gene fusion was nearly identical to the $\operatorname{clp} Q^{+} Y^{+}$transcript under the in vivo condition. The $\operatorname{clp} Q^{m l}:: l a c Z^{+}$, containing a point mutation in the -10 promoter region for $\mathrm{RpoH}$ binding, showed decreased $\beta \mathrm{Gal}$ activity, independent of activation by $\mathrm{RpoH}$. We conclude that RpoH itself regulates $c l p Q^{+} Y^{+}$gene expression. In addition, the $c l p Q^{+} Y^{+}$message carries a conserved $71 \mathrm{bp}$ at the 5 ' untranslated region (5'UTR) that is predicted to form the stem-loop structure by analysis of its RNA secondary structure. The $\operatorname{clp} Q^{m 2} \Delta 40:: l a c Z^{+}$, with a 40 bp deletion in the 5'UTR, showed a decreased $\beta$ Gal activity. In addition, from our results, it is suggested that this stem-loop structure is necessary for the stability of the $\operatorname{clp} Q^{+} Y^{+}$message.
\end{abstract}

Key Words: Promoter activity, Gene regulation, E. coli, ClpYQ (HsIUV), ATP-dependent protease, 5' stem-loop structure, mRNA stability.

\section{INTRODUCTION}

The $E$. coli $\operatorname{clp} Q^{+} Y^{+}$operon, encoding an ATP-dependent protease, was originally discovered as part of the heat shock apparatus [1]. In the $\operatorname{clp} Q^{+} Y^{+}$operon, the first gene, $\operatorname{clp} Q^{+}$, encodes a small peptidase of $19 \mathrm{KDa}$, and the second gene, clp $Y^{+}$, encodes an ATPase large subunit of $50 \mathrm{KDa}$ [1-3]. In the presence of ATP, the ClpYQ complex forms an active protease with an $\mathrm{Y}^{6} \mathrm{Q}^{6} \mathrm{Q}^{6} \mathrm{Y}^{6}$ configuration $[2,3]$. Biochemical and genetic analyses have shown that the cellular proteins, SulA, RcsA, and RpoH are degraded by the ClpYQ protease [4-11], and that ClpY interacts with SulA in the yeast two-hybrid assays [12]. It was recently reported that Cpx-mediated TraJ degradation by ClpYQ is a stressmediated response [13]. The most recent aspects for the study of the biological activity of the ClpYQ ATP-dependent protease is reviewed in $\mathrm{Wu}$ et al., 2008 [14].

Heat shock responses are typically observed in E. coli (reviewed in [15-17]). Upon heat shock, protein misfolding leads to a cascade of intracellular protein synthesis, usually dependent on a sigma factor, i.e., $\sigma^{32}$, for their gene expression. The $\sigma^{32}$ consensus binding sequences are found in the upstream region of the $c l p Q^{+} Y^{+}$operon and its mRNA production is increased upon heat shock induction (Fig. 1A) [1]. However, no empirical experiment was performed to directly

*Address correspondence to this author at the Department of Agricultural Chemistry, National Taiwan University, Taipei (106), Taiwan, R.O.C. Tel: (8862)-3366-2212; or (8862)-3366-4818; Fax: (8862)-2363-3123;

E-mail: whifinwu@ntu.edu.tw identify that the $\mathrm{RpoH}\left(\sigma^{32}\right)$ is responsible for the heat shock induction of $c l p Q^{+} Y^{+}$. In addition, the transcriptional start point of the $\operatorname{clp} Q^{+} Y^{+}$gene lies 71 bases upstream from the clp $Q^{+}$start codon (Fig. 1A). An untranslated region (UTR) upstream of this mRNA contains a $20 \mathrm{bp}$ inverted repeat (IR) sequence 5'CCCCGTACTTTTGTACGGGG3', which is unique for the $\operatorname{clp} Q^{+} Y^{+}$operon (Fig. 1A). In addition, from the wild bacterial genome, the 5'UTR of $\operatorname{clp} Q^{+} Y^{+}$also exists in other bacterial species (Fig. 1B).

In this study, we analyzed $\operatorname{clp} Q^{+} Y^{+}$mRNA production in wild-type (wt) cells versus sigma-factor deficient mutants using a $\lambda \operatorname{clp} Q^{+}:: l a c Z^{+}$fusion gene, in which a chromosomal clp $Q^{+} Y^{+}$promoter is fused with a $\operatorname{lac} Z^{+}$reporter. We demonstrated that the expression of the lac $Z$ reporter gene is induced in the wild-type cells but not in $r p o H$-deficient mutants under the heat shock induction. The $\operatorname{clp} Q^{m l}: \because l a c Z^{+}$fusion gene, carrying a $\mathrm{C}$ to $\mathrm{T}$ mutation in the -10 promoter site for RpoH-binding, showed a decreased gene expression. No additional sigma factor was identified for an activation of its gene expression. Thus, through a genetic analysis, the clp $Q^{+} Y^{+}$promoter is in vivo recognized by $\sigma^{32}$. In addition, a stem-loop structure (IR) at the 5' end of the UTR of $\operatorname{clp} Q^{+} Y^{+}$ mRNA is shown to be necessary for $\operatorname{clp} Q^{+} Y^{+}$gene expression.

\section{MATERIALS AND METHODOLOGY}

\section{Materials and Media}

Bacterial strains and phages used in this study are listed in Table 1. LB complex media was purchased from Difco 
(A)

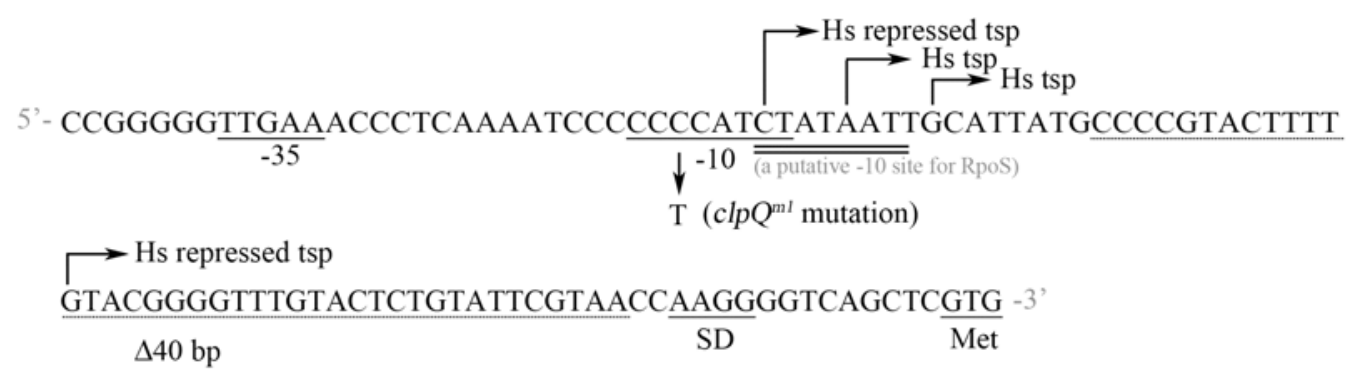

Consensus sequences of $\sigma^{32}(\mathrm{rpoH})$

5' G $\sim \underline{\mathrm{C} \sim \mathrm{CCCCAT} \sim \mathrm{T}}$ 3'

$-10$

(B)

$$
\begin{aligned}
& \text { E. coli } 5 \text {,--.--CCCCGTACTTTTGTACGGGGTTTGTACTCTGTATTCGTAACCAAGGGGTCAGCTCGTG-3, } \\
& \text { S. flexneri } 5 \text {,--.-CCCGTACTTTTGTACGGGGTTGTACTCTGTATTCGTAACDAAGGGGTCAGCTCGTG-3, } \\
& \text { S. enterica } 5 \text { '---GCCCGTACGCCGTACGGGGCCGCAATTCAGCATTAGTAACCAAGGGGTCTGCTCGTG-3' } \\
& \text { K. pneumonia } \quad 5 \text { ' GGCCCCGCGGACAGCGCGGGGCCCCTGTTCCGCTTTTGCAACCAAGGGGTCTGCTCGTG-3' } \\
& \text { Enterobacter } s p . \quad 5 \text {.---GCCTGAGTATCAGCTCAGGGCATCTCTTTCGAATTTGTAACCAGGGGGTCTGCTCGTG-3', } \\
& \text { Serratia sp. 5'-CCTCGTAGTGTCTGCGCAAGCAGATACTGCGAGGGCTTCTTTCCGTCTTCAACGAGGGTCTGCTCGTG-3' } \\
& \text { Y. pestis. } 5 \text { '--CTCCGTACTGTTTTTAACAGGCAGTACGGGGACTCATTCAGTCTGCAACGAGGGTCTGCTCGTG-3' } \\
& \text { Erwinia } s p \text {. } 5 \text { '---GCCCACACTGACGTGTGGGGCCGT---_CTTTTTGACTGTAACAAGGGGTCTGCCCGTG-3' } \\
& \text { Citrobacter } s p \text {. } \quad 5 \text { '--- }
\end{aligned}
$$

Fig. (1). (A) Nucleotide sequences of the promoter region of the $\operatorname{clp} Q^{+} Y^{+}$operon [1]. The transcriptional start site is shown by arrows. The consensus -10 and -35 sequences recognized by $\sigma^{32}$ are underlined. The SD region and the start codon GTG of $c l p Q^{+} Y^{+}$are as specified. The $c l p Q^{m l}$ carries a $\mathrm{C}$ to $\mathrm{T}$ nucleotide substitution in the region of the $\mathrm{RpoH}-10$ promoter element. The dotted line indicates the deletion of 40 bps in the leader sequence in front of the translational start codon in the $c l p Q^{m 2} \Delta 40:$ :lac $Z^{+}$fusion gene. (B) The conserved regions of sequences from the 5'UTR of the $c l p Q^{+} Y^{+}$genes were aligned among the different bacterial species. The bacteria are present mainly in the Enterobacteriaceae family, i.e. Escherichia coli, Shigella flexneri, Salmonella enterica subsp. Enteritidis, Klebsiella pneumonia, Enterobacter sp., Serratia proteamaculans, Yersinia pestis, Erwinia tasmaniensis and Citrobacter koseri. The sequence that forms a hairpin structure is underlined and the IR sequence is highlighted. The Shine-Darlgarno sequence is boxed and the translational start site is in bold.

and the bacteria were grown in LB broth, with an addition of the appropriate antibiotics as required. Supplements were added as the following final concentrations when needed: $100 \mu \mathrm{g}$ ampicillin (Ap) $\mathrm{ml}^{-1} ; 40 \mathrm{mg} \mathrm{X}$-gal $\mathrm{ml}^{-1}$. The Taq DNA polymerase, restriction endonucleases, and other enzymes were obtained from Takara, New England BioLabs and Biolab (Taipei). Chemicals were obtained from Sigma or Wako.

\section{P1 Transduction and Other General Methods}

P1vir, $\lambda$ derivative phages, and transduction were prepared as described by Silhavy et al. [23]. Mutant strains were constructed by $\mathrm{P} 1$ transduction by procedures as described by Miller [24]. For plasmid constructions, E. coli XL-1 blue competent cells were used. Plasmid transformations were performed as described by Chung et al. [25]. Plasmid purification was performed according to the instructions of manufacturers (Viogene).

\section{Primers, Construction of Plasmids and DNA Sequencing}

The forward $(\mathrm{F})$ and reverse $(\mathrm{R})$ primers used in this study were listed below with the restriction enzyme site un- derlined and the substituted nucleotides bold. F1: 5'-CG GAATTCCCGGGGGTTGAAA-3', F2: 5'-CCGGAATTC AGCCGTACCAGGATCTGCTGCAAACTCCTG-3', F3: 5'CCGAATTCCCGGGGGTTGAAACCCTCAAAATCCCCCTCATCTATAATTGCATTATGCCCCGTA-3', F4: 5'-CC ATCTATAATTGCATTATGCCAAGGGGTCAGCT-3', F5: 5'-GGGGTACCCATCTATAATTGCATTATGCCC-3', F6: 5'-GGGGTACCTTTGTACTCTGTATTCGTAAC-3', the F7: 5'-GGGGTACCCCAAGGGGTCAGCTCGTGACAA-3', F8: 5'-GGGGTACCCATCTATAATTGCATTATGCCCCGTA CTTTTTTTTTTTTTTTGTACTCTGTATTCGTAACCAA GGGGTCAG-3', F9: 5'-GGGGTACCCATCTATAATTGC ATTATGGGGGCATGTTTTCATGCCCCTTTGTACTCTG TATTCGTAACCAAGGGGTCAG-3', R1: 5'-GCGGGATCC ACATGGCCGTTACGGC-3', R2:5'-CATAATGCAATTAT AGATGG-3', R3: 5'-CGCGGATCCGCATCCGCAGTACC GCCCGCAAAG-3'. R4: 5'-CCCAAGCTTTTACGCTTTGT AGCTTAATT-3'. All the plasmids, used in this study, were listed in Table 2. Plasmids pSY1 $\left[\operatorname{clp} Q^{+} Y^{+}\right.$promoter (141 bps)-lac $Z^{+}$, in pRS415], pSY2 [clp $Q^{+} Y^{+}$promoter (141 bps)lacZ' in pRS414], pSY3 [clp $Q^{+} Y^{+}$promoter (478 bps)lac $Z^{+}$, in pRS415] and pSY4 $\left[c l p Q^{+} Y^{+}\right.$promoter (478 bps)- 
Table 1. The E. coli Strains and Phages Used in this Study

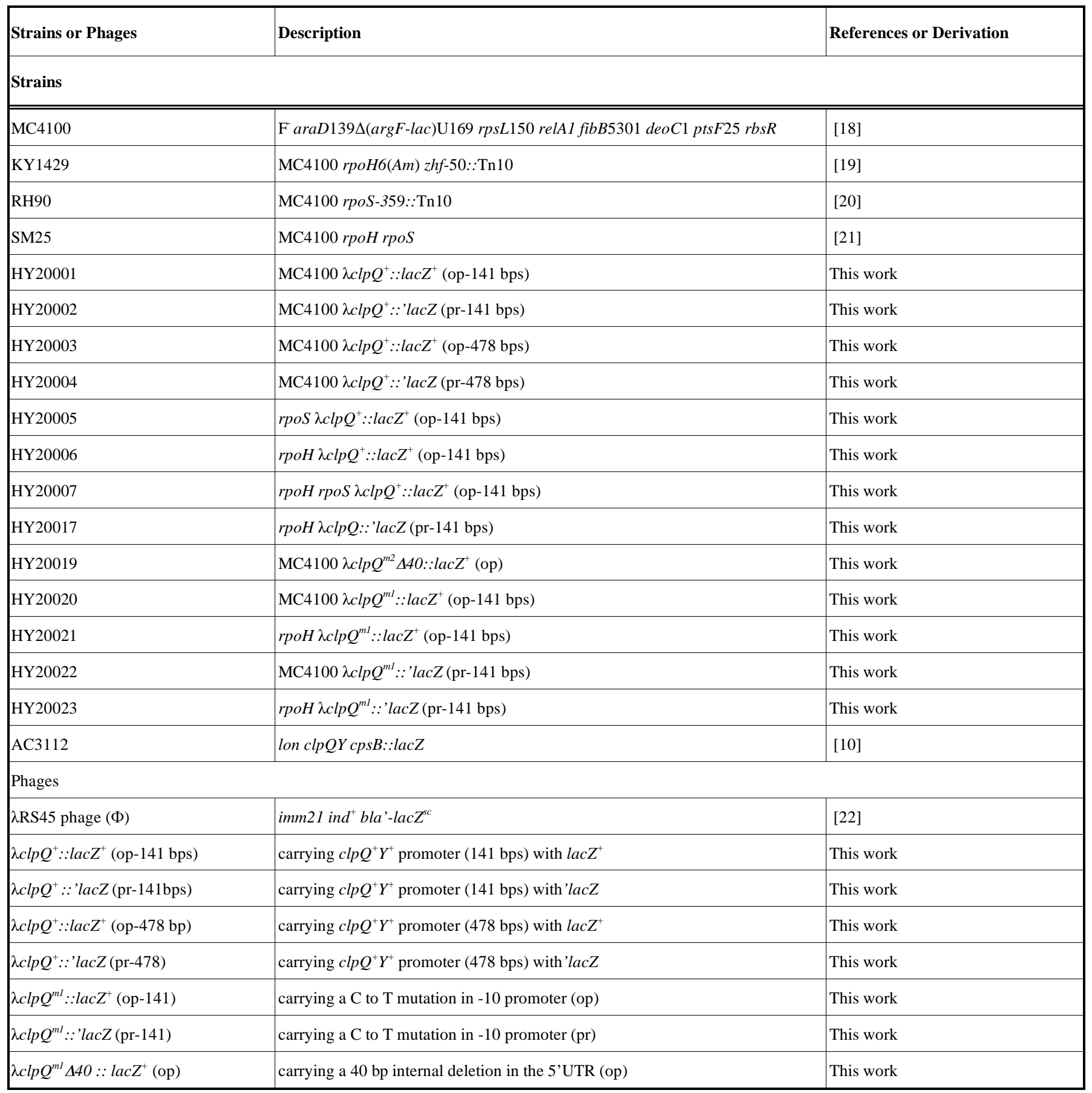

lacZ', in pRS414] were constructed as follows. The plasmid, pWPC80 [9], was used as a template for an amplification of a promoter region of $\operatorname{clp} Q^{+} Y^{+}$. The PCR was used to amplify the genes surrounding the upstream region, including the $\operatorname{clp} Q^{+} Y^{+}$promoter, the Shine-Dalgarno (SD) site, and the first thirteen amino acids of $\operatorname{clp} Q^{+}$, and the resulting DNA fragment was fused in-frame to lacZ' in pRS414 [22], a translational lacZ' fusion (pr) plasmid [22]; this upstream region was also cloned separately in front of $\mathrm{lac}^{+}$in pRS415 plasmid with a transcriptional $\operatorname{lac}^{+}$fusion (op). Two sets of primers were used. Set 1: F1 and R1. Set 2: F2, R1. The PCR conditions were performed according to the manufacturer's instructions, and then the PCR products were purified with Viogene Gel-M kits. Both pRS414 and pRS415 plasmids were cut with EcoRI and BamHI and ligated with the DNA fragments treated with the same restriction enzymes. The resulting ligated mixtures were then transformed into the E. coli XL-1 blue, and the transformants were selected on ampicillin agar plates. Plasmids isolated from colonies grown on the selective media were subjected to restriction enzyme analysis, followed by DNA sequencing. To construct $\operatorname{clp} Q^{m l}: \because l a c Z^{+}$, with a $\mathrm{C}$ to $\mathrm{T}$ mutation, a set of primers was 
Table 2. The Plasmids Used in this Study

\begin{tabular}{|c|c|c|}
\hline pRS415 & bal-T14-EcoRI-SmaI-BamHI-lacZ ${ }^{+}$ & [22] \\
\hline pWPC80 & pACYC184 with $\operatorname{clp} Q^{+} Y^{+}$and its surrouding sequences & [9] \\
\hline pWF1 & pACYC184(Tet $\left.{ }^{\mathrm{r}}\right)-\operatorname{clp} Q^{+} \operatorname{clp} Y^{+}$ & [9] \\
\hline pSY2 & $\operatorname{clp} Q^{+} Y^{+}$promoter (141 bps)-lacZ in pRS414 & This work \\
\hline pSY3 & $\operatorname{clp} Q^{+} Y^{+}$promoter (478 bps)-lac $Z^{+}$in pRS415 & This work \\
\hline pSY4 & $c l p Q^{+} Y^{+}$promoter (478 bps)-lacZ' in pRS414 & This work \\
\hline pSY8 & pRS414-clp $Q^{m 2} \Delta 40: \because l a c Z$ & This work \\
\hline pBAD33 & ori $\left(\mathrm{pACYC} 184, \mathrm{Cm}^{\mathrm{r}}\right) \operatorname{araC} \mathrm{P}_{\mathrm{BAD}}$ & {$[26]$} \\
\hline pSY9 & pBAD33-clp $Q^{+}$ & This work \\
\hline pSY10 & pBAD33- $\Delta I R-\operatorname{clp} Q^{+}$ & This work \\
\hline pSY11 & $\mathrm{pBAD} 33-\Delta L-c l p Q^{+}$ & This work \\
\hline pSY12 & pBAD33-(S-IR)-clp $Q^{+}$ & This work \\
\hline pSY13 & pBAD33-(R-IR)-clp $Q^{+}$ & This work \\
\hline
\end{tabular}

used as follows: F3 and R1. Similar procedures as described above were used to clone the PCR fragment carrying $\operatorname{clp} Q^{m 1}$ upstream of $l a c Z$. Two resulting plasmids, $\operatorname{clp} Q^{m l}:: l a c Z^{+}$ in pRS415 and $c l p Q^{m l}: \because$ lac $Z^{\prime}$ in pRS414, were designated pSY5 and pSY6, respectively. Several PCR steps were then used to construct a $c l p Q^{m 2} \Delta 40: \because l a c Z^{+}$, with a 40 bp deletion in the internal region of UTR upstream of the fusion gene. To construct a $c l p Q^{m 2} \Delta 40$ mutation, a two-step PCR was used to amplify the $\operatorname{clp} Q^{+}$promoter and its adjacent region. The upstream region primers were F2 and R2. The downstream primers were F4 and R3. Two overlapping PCR fragments were then used as the template and were amplified by the primers of F2 and R3. The resulting DNA fragment with a 40 bp deletion within the leader sequences (as shown in Fig. 1A) was cloned into pRS415 and pRS414 at EcoRIBamHI sites, and the resulting plasmids were designated pRS415-clp $Q^{m 2} \Delta 40: \because l a c Z^{+}(\mathrm{pSY} 7)$ and $\mathrm{pRS} 414-c l p Q^{m 2} \Delta 40::$ lacZ' (pSY8), respectively.

Plasmids pBAD33-clpQ $Q^{+}$(pSY9), pBAD33- $\Delta I R-\operatorname{clp} Q^{+}$ (pSY10) and pBAD33- $\Delta L-c l p Q^{+}(\mathrm{pSY} 11)$ were constructed as described below. Using the pWF1 [9] as the template, the various DNA fragments surrounding the upstream region of $c l p Q^{+}$gene and the upstream region alone were separately PCR-amplified. The resulting DNA fragments were cloned in series into the pBAD33 at the KpnI-HindIII sites, and the cloned genes were all under the pBAD promoter control. Consequently, the plasmid pBAD33-clp $Q^{+}$carries the upstream 71 nucleotides from the translational start site of $\operatorname{clp} Q^{+}$and $\operatorname{clp} Q^{+}$itself. The F5 and R4 primers were used. The plasmid pBAD33- $\Delta I R-\operatorname{clp} Q^{+}$, which contains 35 nucleotides upstream of the GTG initiative codon of $\operatorname{clp} Q^{+}$and $\operatorname{clp} Q^{+}$itself under the pBAD promoter, was constructed, using F6 and R4 primers to amplify a DNA fragment of $\Delta I R$ $\operatorname{clp} Q^{+}$. The plasmid pBAD33- $\Delta L-c l p Q^{+}$was constructed, in which the 15 nucleotides upstream of the first GTG codon and $\operatorname{clp} Q^{+}$itself were under the pBAD promoter control. To generate $\Delta L$-clp $Q^{+}, \mathrm{F} 7$ and $\mathrm{R} 4$ primers were used. In addition, the plasmid pBAD33- $(S-I R)-c l p Q^{+}$(pSY12) was constructed, which carries the substituted $\mathrm{T}$ sequences at the 5 , end of the UTR of $c l p Q^{+}$(indicated with bold in the primer $\mathrm{F} 8)$, using the F8 and R4 primers. Plasmid pBAD33-( $R-I R)-$ $\operatorname{clp} Q^{+}$(pSY13) carries the substituted nucleotides at the 5' end of UTR of $\operatorname{clp} Q^{+}$, resulting in a newly introduced secondary structure. The F9 and the R4 primers were used for generating the DNA fragment of $(R-I R)-\operatorname{clp} Q^{+}$. The plasmid pBAD24-clp $Y^{+}$(pSY14) was constructed as follows. Using the pWF1 as the template, the $\operatorname{clp} Y^{+}$was amplified, and the resulting DNA fragment was cloned into the pBAD24 at the 
EcoRI-HindIII cutting sites [10, 26]. All the constructed plasmids with the correct DNA insert were identified by restriction enzyme mapping as well by DNA sequencing.

\section{Construction of $\lambda \operatorname{clp} Q::$ lacZ Fusion Gene}

Plasmids pSY1 ( $\operatorname{clp} Q^{+}::$lac $Z^{+}$, op-141), pSY2 (clp $Q^{+}:: \operatorname{lac} Z$, pr-141), pSY3 (clp $Q^{+}::$lac $Z^{+}$, op-478) and pSY4 $\left(\operatorname{clp} Q^{+}:: l a c Z\right.$, pr-478) were made. These four plasmids were transformed into the E. coli XL-1 blue, and the resultant transformants $\left(A p^{r}\right)$ were selected on ampicillin plates. The transformant cells were then infected with the lambda derivative $\lambda$ RS45 and selected for blue plaques on $\mathrm{X}$-gal plates leading to $\operatorname{clp} Q^{+}: \because l a c Z^{+}$transcriptional or $\operatorname{clp} Q^{+}:: '$ lac $Z$ translational fusion genes transferred into $\lambda \mathrm{RS} 45 \Phi$ [22]. The derivative $\lambda \mathrm{RS} 45 \Phi$ clpQ $:: \mathrm{lac}^{+}$(or $\lambda$ clp $Q^{+}::$'lacZ) fusion gene was made with different upstream length of the $\operatorname{clp} Q^{+} Y^{+}$promoter. Each phage lysate was used to infect $E$. coli and the resultant single phage lysogen was selected. A single phage lysogen was identified by measurement of $\beta \mathrm{Gal}$ levels of five lysogens, and those with the lowest expression value were selected as the single lysogens.

\section{The $\beta$ Gal Assays}

The $\beta \mathrm{Gal}$ activities were assayed as described by Miller [24]. The cells were grown to log phase, and activity was measured by the $\beta \mathrm{Gal}$ assay. All of the $\beta$ Gal activity was determined in triplicate for each assay. Each analysis was repeated at least three times.

\section{Northern Hybridization Assays}

The cells were grown in $5 \mathrm{ml}$ of broth to exponential phase at $30{ }^{\circ} \mathrm{C}\left(\mathrm{OD}_{600}\right.$ about 0.5$)$. At each time point, total RNA was isolated by Qiagene RNeasy Mini kits. Equal amounts of total RNA ( $3 \mu \mathrm{g}$ each) were separated under denaturing conditions in a $1 \%$ agarose- $2.1 \mathrm{M}$ formaldehydeMOPS [morpholinopropane-sulfonic acid] gel, stained with ethidium bromide, and blotted onto nitrocellulose (Schleicher \& Schuell) with 20X SSC. The DNA probes were labeled with DIG-dUTP by random priming (Roche). The DNA fragments used for probes were obtained by PCR amplification. The $401 \mathrm{bp}$ DNA fragment corresponding the $c l p Q^{+}$structural gene was used as a probe for $\operatorname{clp} Q^{+}$mRNA, and a 723 bp DNA fragment containing a lac $Z^{+}$gene was used as a probe for the $c l p Q^{+}:: l a c Z^{+}$mRNA. The membrane was hybridized with the appropriate probe and washed. The signals were produced by an addition of the anti-DIG antibody with fluorescent alkaline phosphatase conjugate and CDP-star (NEB BioLabs) to the membrane and visualized by an exposure to an X-ray film.

\section{The cpsB::lacZ Assays and the Western-blot Analysis for ClpQ}

Cells, AC3112 (lon, clpQY, cpsB::lacZ) [10] carrying plasmids pBAD33-clp $Q^{+}$, pBAD33- $\Delta I R-\operatorname{clp} Q^{+}$, pBAD33$\Delta L-c l p Q^{+}, \mathrm{pBAD} 33-(S-I R)-c l p Q^{+}$, or pBAD33-(R-IR)-clp $Q^{+}$ in combination with pBAD24-clp $Y^{+}$plasmids were grown overnight on LB with ampicillin $(50 \mu \mathrm{g} / \mathrm{ml})$ and chloramphenicol $(12.5 \mu \mathrm{g} / \mathrm{ml})$ with an addition of arabinose $(0.5 \%)$ to induce the $\mathrm{P}_{\mathrm{BAD}}$ promoter. The overnight cultures were inoculated 1:100 into fresh media with the above indicated ingredients and were grown into log phase, and then half of the cells were immediately subjected to the $\beta \mathrm{Gal}$ assays for the cpsB::lacZ expression. The other half of the log cells were harvested and subjected to the western blot analysis. The polyclonal ClpQ antibody was used to detect the ClpQ protein, which was separately encoded by the above three plasmids pBAD33-clpQ $Q^{+}$, pBAD33- $\Delta I R-c l p Q^{+}$and $\mathrm{pBAD} 33-$ $\Delta L$-clp $Q^{+}$. The procedure was adopted as described previously [12]. The western blots were developed by the enhanced chemiluminescence (Pierce).

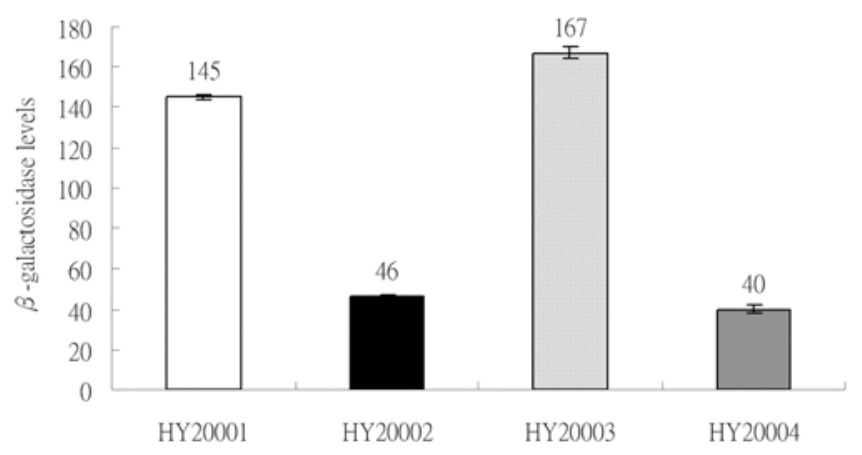

Fig. (2). Expression of two sets of $\lambda \operatorname{clp} Q^{+}:: l a c Z$ gene fusion, in a transcriptional or a translational fusion type, with two different lengths of the $\operatorname{clp} Q^{+}$promoter. The $\beta \mathrm{Gal}$ activities are represented as bars, from left to right, HY20001 (op-141 bp), HY20002 (pr-141 bp), HY20003 (op-478 bp) and HY20004 (pr-478 bp). The lysogens were cultivated on LB media to $\log$ phase at $30{ }^{\circ} \mathrm{C}$, and the enzyme assays were performed in triplicate at least three times.

\section{RESULTS}

\section{The Expression of $\operatorname{clp} Q^{+}:: \operatorname{lac} Z$ Fusion Gene in $\lambda \mathbf{R S 4 5}$}

To monitor the expression of the $\operatorname{clp} Q^{+} Y^{+}$genes in $E$. coli, two sets of $\operatorname{clp} Q^{+}:: l a c Z$ fusion genes were made; in each one, the $\operatorname{clp} Q^{+} Y^{+}$promoter is in front of lacZ. Both fused genes have the lac $Z$ gene under the $\operatorname{clp} Q^{+} Y^{+}$promoter control, but they carry the different length of the upstream sequence in either a transcriptional or a translational fusion type. After transferring these four $\operatorname{clp} Q^{+}:: l a c Z$ fusion gene into the $\lambda \mathrm{RS} 45$, the resulting phages, $\lambda \operatorname{clp} Q^{+}:: \operatorname{lac}^{+}$(op-141 bp), $\lambda \operatorname{clp} Q^{+}:: '$ lacZ (pr-141 bp), $\lambda c l p Q^{+}:: l a c Z^{+}$(op-478 bp), and $\lambda \operatorname{clp} Q^{+}:{ }^{\prime} l a c Z$ (pr-478 bp), were separately lysogenized into a lacZ-deficient strain (MC4100). These four newly lysogens were isolated, namely, HY20001, HY20002, HY20003 and HY20004, correspondingly. The $\beta$ Gal activity was then measured for the each single phage lysogen. Despite the two different sizes of the $\operatorname{clp} Q^{+} Y^{+}$promoter fragments (141 bps or $478 \mathrm{bps}$ ), the two lysogens in a transcriptional type (HY20001 and HY20003) had an almost equal $\beta \mathrm{Gal}$ activity of lac $Z$ gene fusion (Fig. 2); similarly this was observed in a translational type (HY20002 and HY20004) (Fig. 2). Thus, only one set of lysogens (the op and $\mathrm{pr}$ lacZ fusion gene with an identical length of the upstream $\operatorname{clp} Q^{+} Y^{+}$promoter) would be used for the further analysis.

\section{$\mathrm{ClpQ}^{+} \mathrm{Y}^{+}$Promoter-Mediated Basal and Heat Shock- Induced Gene Expression Requires RpoH}

It was shown that $c l p Q^{+} Y^{+}$promoter has the $\mathrm{RpoH}\left(\sigma^{32}\right)$ binding site [1]. However, a putative -10 site for an 
$\operatorname{RpoS}\left(\sigma^{38}\right)$-binding was partially overlapped with the similar $\mathrm{RpoH}$ recognition site (Fig. 1A). Therefore, to further identify that RpoH and/or RpoS have effects on $\operatorname{clp} Q^{+} Y^{+}$gene expression, the $\lambda c l p Q^{+}: \because l a c Z^{+}$(op-141 bp) was lysogenized into the wild-type strain MC4100 [18], and mutant strains KY1429 (rpoH) [19], RH90 (rpoS) [20], and the double mutant SM25 (rpoH rpoS) [21]. The four resulting lysogens all carried $\lambda \operatorname{clp} Q^{+}::$lac $Z^{+}$(op-141 bp) as a prophage. The basal and heat induction of the $\operatorname{clp} Q^{+}: \because$ lac $Z^{+}$gene expression were measured among these four lysogens: HY20001 (the wildtype), HY20005 (rpos), HY20006 (rpoH) and HY20007 (rpoS rpoH). HY20001 and HY20005 have identical $\beta \mathrm{Gal}$ activity at $30{ }^{\circ} \mathrm{C}$ (Fig. 3). In contrast, HY20006 (rpoH) and HY20007 (rpoS rpoH) show a decreased $\beta$ Gal activity (Fig. 3). At $42{ }^{\circ} \mathrm{C}$, the wild-type HY20001 and the HY20005 (rpoS) mutant have increased $\beta \mathrm{Gal}$ activity, whereas HY20006 (rpoH) and HY20007 (rpoS rpoH) maintain a basal expression (Fig. 3). Thus, RpoH, but not the RpoS, appears to control the $\operatorname{clp} Q^{+}: \because l a c Z^{+}$gene expression, and the clp $Q^{+}:: l a c Z^{+}$expression increases under the heat induction.

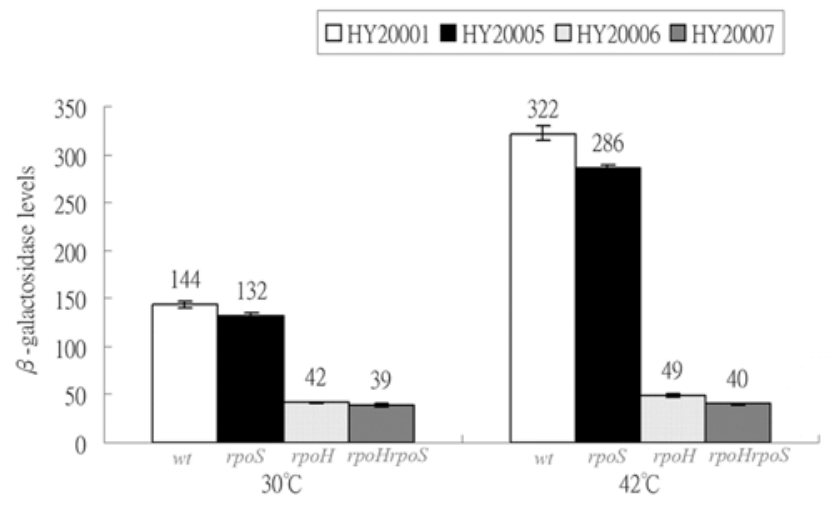

Fig. (3). Expressions of $\lambda \operatorname{clp} Q^{+}: \because l a c Z^{+}$in the wild-type and the various sigma- factor deficient strains. HY20001 (the wild-type), HY20005 (rpoS), HY20006 (rpoH) and HY20007 (rpoH rpoS) are as indicated at $30{ }^{\circ} \mathrm{C}$ or $42{ }^{\circ} \mathrm{C}$. The lysogens were cultivated at 30 ${ }^{\circ} \mathrm{C}$ first for $\log$ growth and then shifted to $42{ }^{\circ} \mathrm{C}$ for $20 \mathrm{~min}$.

The mRNA Transcripts of $\operatorname{clp} Q^{+}:: l a c Z^{+}$and $c l p Q^{+} Y^{+}$in Wild-Type and RpoH/RpoS Mutants

Northern blot analyses were used to demonstrate that the $\operatorname{clp} Q^{+}::$lac $Z^{+}$mRNA expression is well correlated with its $\beta \mathrm{Gal}$ levels in the above bacterial strains. Total RNA was isolated from the wild-type cells (HY20001), rpoS (HY20005), rpoH (HY20006), and rpoH rpoS (HY20007) double mutants at $30{ }^{\circ} \mathrm{C}$. Using a $l a c Z^{+}$probe, significant RNA transcripts of $c l p Q^{+}:: l a c Z^{+}$were observed in the wildtype and the $\operatorname{rpoS}$ mutant, whereas only a minor transcript was detected in the $\sigma^{32}$-deficient mutant, HY20006, and in the double mutant rpoS rpoH, HY20007 (Fig. 4A). Similar results were observed using a $\operatorname{clp} Q^{+}$probe to detect the $\operatorname{clp} Q^{+} Y^{+}$mRNA production among the wild-type and the various sigma-factor deficient strains (Fig. 4B).

\section{Expression of $\operatorname{clp} Q^{m 1}:: l a c Z$, with a $\mathrm{C}$ to $\mathrm{T}$ Mutation in the -10 RpoH-biding Site}

To reversely show that a specific mutation at the promoter region of $\operatorname{clp} Q^{+} Y^{+}$also has an effect on its gene ex- pression, a $\mathrm{C}$ to $\mathrm{T}$ cis-mutation in the -10 promoter region was made in both pRS414-clpQ $Q^{m l}: \because l a c Z$ ' and pRS415$\operatorname{clp} Q^{m l}: \because l a c Z^{+}$plasmids. The $\operatorname{clp} Q^{m l}$ has a nucleotide substitution, 5'C CCTCATCT3', in the -10 promoter region distinct from the consensus sequence for the RpoH-binding, 5'C CCCCATCT3' (Fig. 1). The two promoter mutant plasmids carrying $\operatorname{clp} Q^{m I}:: \operatorname{lac} Z$ (op or pr fusion) were separately transferred into $\lambda \mathrm{RS} 45$, and the resulting phages were designated $\lambda \operatorname{clp} Q^{m l}:: l a c Z^{+}$(op) and $\lambda \operatorname{clp} Q^{m l}::^{\prime} l a c Z$ (pr), respectively. These two phages were then lysogenized into the wild-type and the rpoH mutant, and the four resultant lysogens were HY20020 (op), HY20021 (op, rpoH), HY20022 (pr), and HY20023 (pr, rpoH). As a control, a lysogen that carries the wild-type $\lambda \operatorname{clp} Q::{ }^{\prime} l a c Z$ (pr-141 bps) in the rpoH background was also made and named HY20017. The $\beta \mathrm{Gal}$ activity was then measured for all the single phage lysogens. As shown, the expression of $\operatorname{clp} Q^{m l}:: l a c Z$ (op or pr fusion) was decreased 1.7 -fold as compared to that of the wild-type $\lambda c l p Q^{+}:: l a c Z$ (Fig. 5) [compare HY 20020 to HY20001 (op) at $30{ }^{\circ} \mathrm{C}$ (Fig. 5A), and HY20022 to HY20002 (pr) at $30{ }^{\circ} \mathrm{C}$ in (Fig. 5B)]. As shown before, the wild-type $\operatorname{clp} Q^{+}:: \operatorname{lacZ}$ (op or pr fusion) increased its expression at $42{ }^{\circ} \mathrm{C}$ [see HY20001 at $42{ }^{\circ} \mathrm{C}$ and at $30{ }^{\circ} \mathrm{C}$ (Fig. 5A) and HY20002 at $42{ }^{\circ} \mathrm{C}$ and at $30{ }^{\circ} \mathrm{C}$ in (Fig. 5B)]. But the gene fusion was not activated in the rpoH mutant (see HY20006 at $30{ }^{\circ} \mathrm{C}$ and at $42{ }^{\circ} \mathrm{C}$ and $\mathrm{HY} 20017$ at $30{ }^{\circ} \mathrm{C}$ and at $42^{\circ} \mathrm{C}$ ). However, $\operatorname{clp} Q^{m l}: \because l a c Z$ (op or pr fusion) was not highly induced at $42{ }^{\circ} \mathrm{C}$ [see HY20020 at $42{ }^{\circ} \mathrm{C}$ and at $30{ }^{\circ} \mathrm{C}$ (Fig. 5A) and HY20022 at $42{ }^{\circ} \mathrm{C}$ and at $30{ }^{\circ} \mathrm{C}$ (Fig. 5B)]. In addition, in the $r p o H$ mutant, $c \operatorname{lp} Q^{m l}: \because l a c Z$ (op or pr fusion) was expressed at a basal or at a slightly lower level than its expression in the wild-type cells [(Fig. 5A) and (Fig. 5B), compare HY20021 to HY20020 and compare HY20023 to $\mathrm{HY} 20022$, at $30{ }^{\circ} \mathrm{C}$ or $42{ }^{\circ} \mathrm{C}$ ]. Thus, $c \operatorname{lp} Q^{m l}$, carrying a $\mathrm{C}$ to $\mathrm{T}$ mutation, has a negative effect on the $\operatorname{clp} Q^{+} Y^{+}$promoter activity, and it is not activated by the RpoH.

(A)

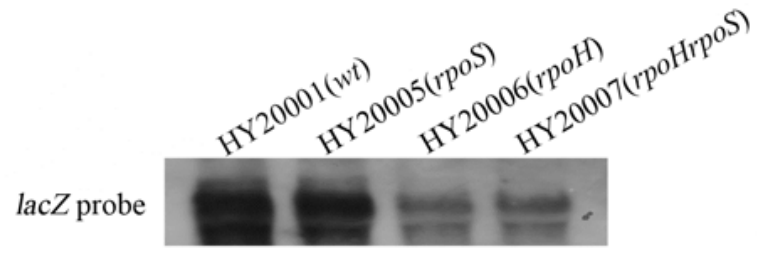

(B)

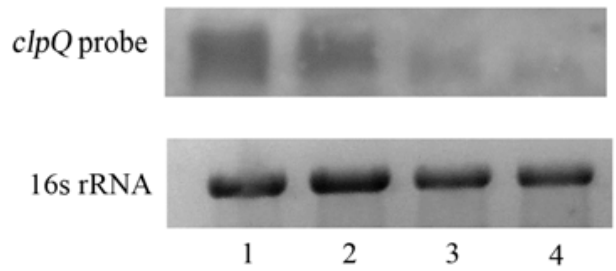

Fig. (4). Northern blots; the total RNA were probed with a DNA fragment of $l a c Z^{+}(\mathbf{A})$, or $\operatorname{clp} Q^{+}(\mathbf{B})$. The HY20001 (the wild-type), HY20005 (rpoH), HY20006 (ropS), and HY20007 (rpoH rpoS) mutants, each carrying $\lambda \operatorname{clp} Q^{+}: \because l a c Z^{+}$, were hosts for the RNA isolation. Each lane contains $3 \mu \mathrm{g}$ RNA for the analysis. The ethidium-bromide stained 16S rRNA was used for normalization of the gel loading. 
(A)
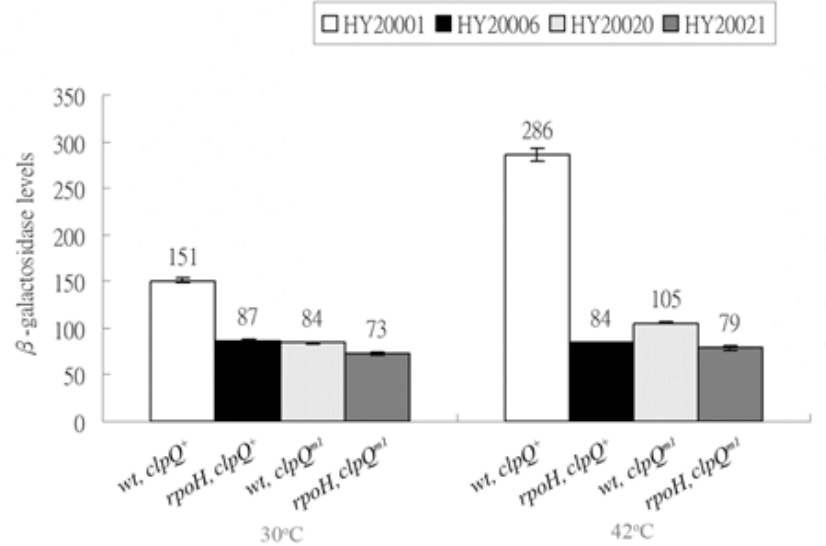

(B)

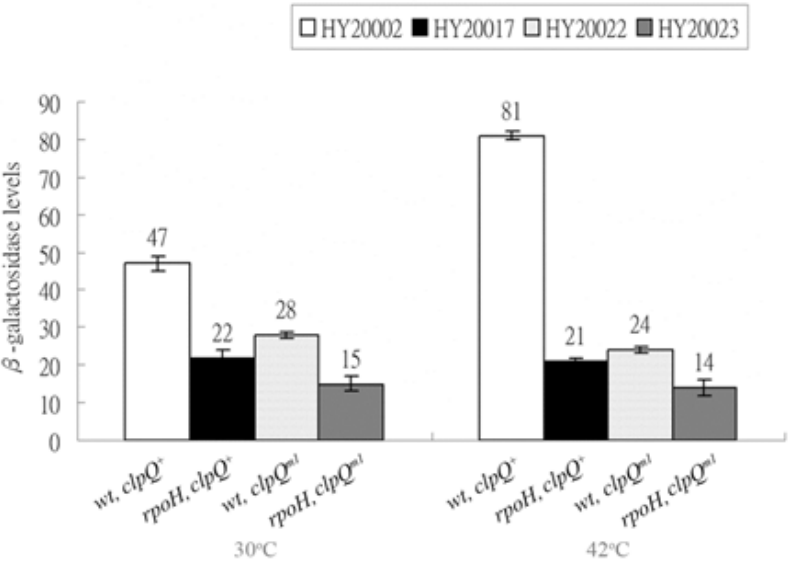

Fig. (5). Expression of the $\lambda \operatorname{clp} Q^{+}::$lacZ (op or pr fusion) and the $\lambda \operatorname{clp} Q^{m 1}: \because l a c Z$ (op or pr fusion) in the wild-type or the rpoH mutant at $30^{\circ} \mathrm{C}$ or $42^{\circ} \mathrm{C}$. (A) The $\beta \mathrm{Gal}$ activities of HY20001 (clp $Q^{+}:: l a c Z^{+}$, op), HY20006 ( $r p o H, c l p Q^{+}:: l a c Z^{+}$, op), HY20020 (clpQ $Q^{m 1}:: l a c Z^{+}$, op), and HY20021 (rpoH, clp $Q^{m l}: \because l a c Z^{+}$, op) are as indicated. (B) In contrast, the $\beta \mathrm{Gal}$ activities of HY20002 (clpQ $Q^{+}::$'lacZ, pr), HY20017

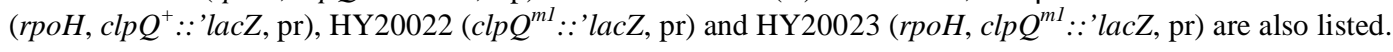

(A)

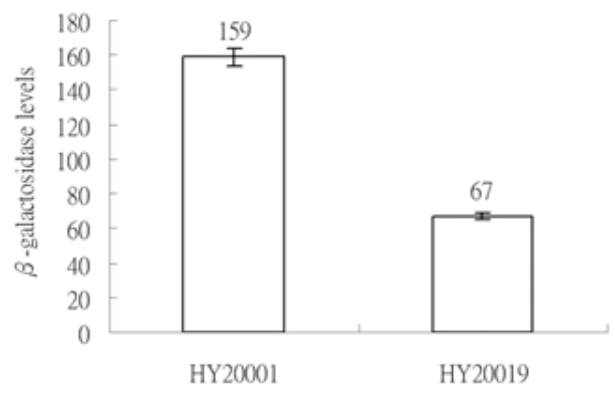

(B)

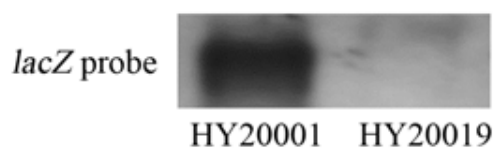

Fig. (6). (A) Expression of the $\lambda c l p Q^{+}:: l a c Z^{+}$in HY20001 and expression of $\lambda c l p Q^{m 2} \Delta 40:: l a c Z^{+}$, with a 40 bp deletion in the internal leader sequences, in HY20019. (B) The northern blot of the mRNAs of these two fusion genes, using the $723 \mathrm{bp}$ of lac $\mathrm{Z}^{+}$as a probe.

\section{Expression of $\operatorname{clp} Q^{m 2} \Delta 40:: l a c Z^{+}$, with a Deletion of $40 \mathrm{bps}$ in the 5'UTR}

The first transcriptional start site of the $\operatorname{clp} Q^{+} Y^{+}$operon was mapped $71 \mathrm{bp}$ upstream from the translational start site. An UTR is present upstream from an initiation codon for the $\operatorname{clp} Q^{+} Y^{+}$operon. It was logically speculated that this UTR might have an effect on $\operatorname{clp} Q^{+}: \because a c Z^{+}$gene expression. To test this possibility, a $\operatorname{clp} Q^{m 2} \Delta 40 b p$ mutation, with a $40 \mathrm{bp}$ deletion of the internal region of the UTR, was constructed in the lac $^{+}$gene fusion [see (Fig. 1)]. This deletion mutant, $\operatorname{clp} Q^{m 2} \Delta 40::$ lac $Z^{+}$, a transcriptional fusion type, was crossed into the $\lambda$ phage, and the resulting phage $\lambda \operatorname{RS} 45 \operatorname{clp} Q^{m 2}$ $\Delta 40:: \operatorname{lac} Z^{+}$(op) was lysogenized into the wild-type cells, MC4100. The newly formed lysogen, HY20019, displayed a significant decrease in $\beta \mathrm{Gal}$ activity, consistent with its mRNA production by northern blot analysis (Fig. 6). In addition, the $\operatorname{clp} Q^{m 2} \Delta 40 b p::^{\prime} l a c Z$ (pr) mutant in a protein fusion construct (pRS414) had much lower $\beta$ Gal activity, and no blue plaques could be selected on the X-gal plates when crossed into the $\lambda$ phage (data not shown).

\section{Functional Activity of Inverted Repeat Sequence in the 5' UTR of $c l p Q^{+} Y^{+}$}

Most single strand RNA form a secondary structure. Utilizing an in silico M-Fold program (http://frontend.bioinfo.rpi.edu/applications/mfold/) [27], a predicted stem-loop structure, including the IR sequence, with a calculated $\Delta \mathrm{G}=-24.6 \mathrm{kcal} / \mathrm{mol}$ was identified in the untranslated leader region (UTR) upstream of the $c l p Q^{+} Y^{+}$structural gene (Fig. 7A-a). To demonstrate that the stem-loop structure is necessary for the expression of $\operatorname{clp} Q^{+} Y^{+}$, DNA fragments with different lengths of the leader sequence upstream of $\operatorname{clp} Q^{+}$were cloned into plasmid pBAD33, and all of the $\operatorname{clp} Q^{+}$ constructs, with different upstream sequences, were under the heterologous pBAD promoter control (induced by arabinose). Three different plasmids were constructed and designated $\mathrm{pBAD} 33-\operatorname{clp} Q^{+}, \mathrm{pBAD} 33-\Delta I R-\operatorname{clp} Q^{+}$and $\mathrm{pBAD} 33-$ $\Delta L$-clp $Q^{+}$, and the secondary structures of the $5^{\prime}$ regions of their $\operatorname{clp} Q^{+}$mRNA were predicted (Fig. 7A-a, b, c.) To evaluate the physiological activity of the above three plasmids encoded $\mathrm{ClpQ}(\mathrm{s})$, we used the $\mathrm{AC} 3112$ strain for an 
assay of a functional ClpQ. Since AC3112, a lon clpQY mutant, carries a cpsB::lacZ, it is expressed a higher $\beta \mathrm{Gal}$ activity due to a stable activator, RcsA [9-11]. When the AC3112 carries both $\mathrm{pBAD} 33-\operatorname{clp} Q^{+}$and $\mathrm{pBAD} 24-c l p Y^{+}$plasmids, it has a decreased $\beta \mathrm{Gal}$ activity of the $\operatorname{cps} B::$ lac $Z$, due to an instability of RcsA, targeted by the ClpYQ under the arabinose induction. AC3112 cells that carry pBAD33 and pBAD24, as a negative control, had higher $\beta$ Gal activities of cpsB::lacZ. However, while cells carrying plasmids pBAD33- $\Delta I R-c l p Q^{+}$or pBAD33- $\Delta L-\operatorname{clp} Q^{+}$, in the presence of pBAD24-clp $Y^{+}$, each bacterial strain had much higher $\beta$ Gal activity from its cpsB::lacZ (Fig. 7B). Western blot analysis was then used to show that ClpQ was accumulated lower in the cells carrying plasmids pBAD33- $\Delta I R-\operatorname{clp} Q^{+}$or pBAD33- $\Delta L-c l p Q^{+}$, as compared to the cells carrying the wild-type pBAD33-clp $Q^{+}$(Fig. 7C). To further identify that the instability of $\operatorname{clp} Q^{+}$mRNA leads to a loss of the functional ClpQ, a northern blot analysis was used to detect the $\operatorname{clp} Q^{+}$messages in all of the above strains. As shown, the mRNA levels of $\Delta I R-\operatorname{clp} Q^{+}$or $\Delta L$-clp $Q^{+}$were much lower than those of $\operatorname{clp} Q^{+}$(Fig. 7D). In addition, the stability of the wild-type $\operatorname{clp} Q^{+}$and $\Delta I R$ - $\operatorname{lp} Q^{+}$mRNAs was measured at different time points after the addition of rifampin to the culture media to block the re-initiation of transcription. Results show that the message of the wild-type $\operatorname{clp} Q^{+}$is much more stable than that of the $\Delta I R-\operatorname{clp} Q^{+}$(Fig. 7E).

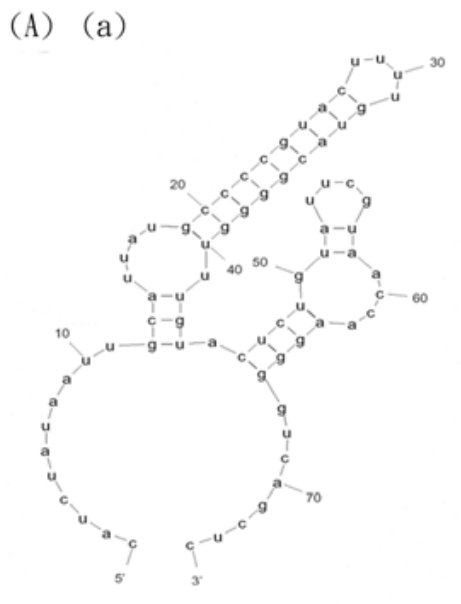

$\triangle \mathrm{G}=-24.6 \mathrm{kcal} / \mathrm{mol}$ (b)

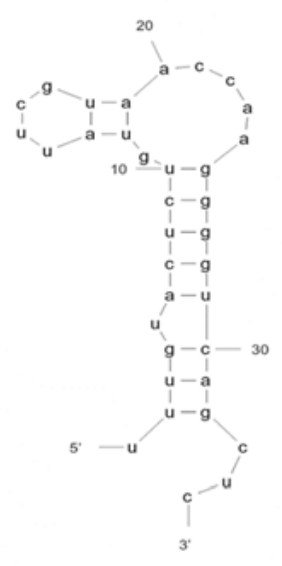

(c)

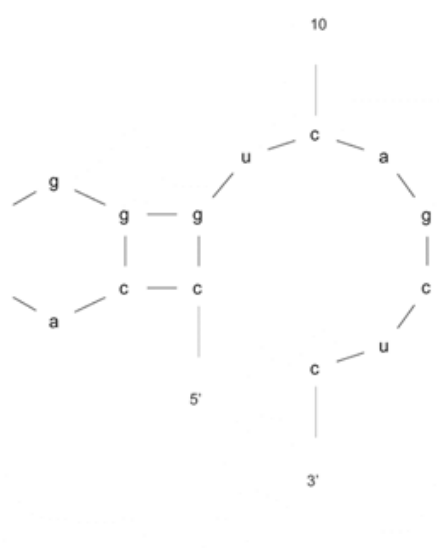

(B)

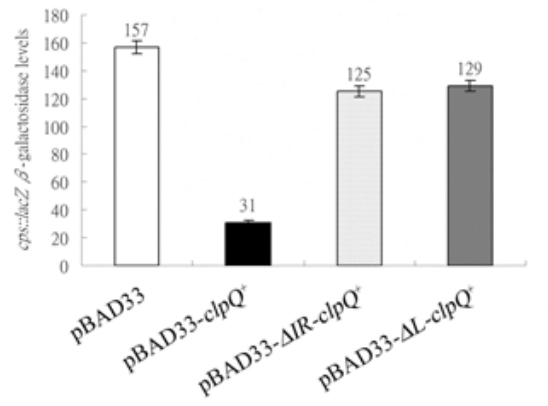

(C)

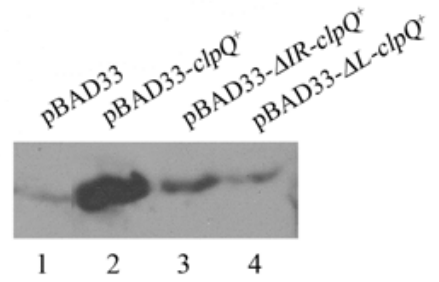

(D)

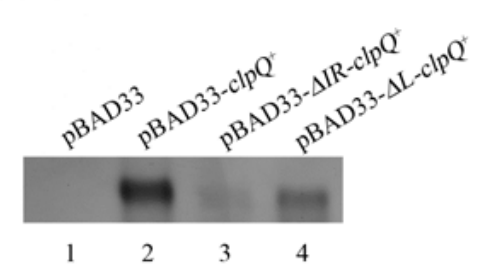

(E) $\triangle \mathrm{G}=-1.3 \mathrm{kcal} / \mathrm{mol}$

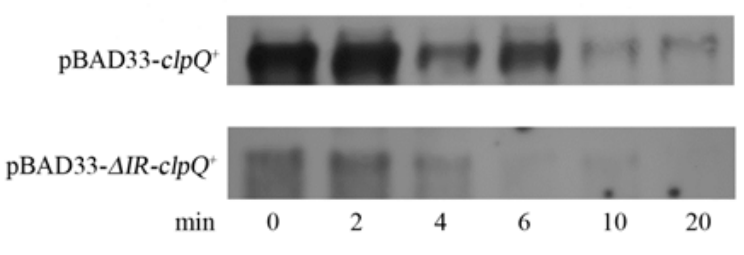

Fig. (7). (A) The secondary structures of the 5' UTR region of the mRNA from (a) $\operatorname{clp} Q^{+}$with $\Delta \mathrm{G}=-24.6 \mathrm{Kcal} / \mathrm{mole}(\mathbf{b}) \Delta I R-c l p Q^{+}$with $\Delta \mathrm{G}$ $=-3.3 \mathrm{Kcal} / \mathrm{mole}$ and (c) $\Delta L-c l p Q^{+}$with $\Delta \mathrm{G}=-1.3 \mathrm{Kcal} / \mathrm{mole}$. (B) The $\beta \mathrm{Gal}$ of $c p s B:: l a c Z$ in the presence of $\mathrm{pBAD} 33, \mathrm{pBAD} 33-c l p Q^{+}$, pBAD33- $\Delta I R-c l p Q^{+}$, or pBAD33- $\Delta L-\operatorname{clp} Q^{+}$, while ClpY was induced. (C) The western blot of ClpQ, expressed, in series, from the above plasmids. The loading was normalized by the readings of $\mathrm{OD}_{600}$. (D) The mRNA of $\operatorname{clp} Q^{+}$, which individually expressed from the above plasmids. The growth condition was as indicated earlier for the addition of antibiotics and $0.5 \%$ arabinose, and the loadings were normalized by $16 \mathrm{~S}$ rRNA (data not shown). (E) The decay of mRNAs of $c l p Q^{+}$and $\Delta I R-c l p Q^{+}$; the remaining amount of mRNA at different time points, after an addition of rifampin (at a final concentration, $200 \mu \mathrm{g} / \mathrm{ml}$ ). 
The Stem-loop Secondary Structure (IR) of 5'UTR of $\operatorname{clp} Q^{+} \boldsymbol{Y}^{+}$Responsible for its mRNA Stability

To further verify that a stem-loop structure at the 5' end of the leader sequences is responsible for the stability of $\operatorname{clp} Q^{+}$mRNA, the substituted nucleotides were placed at the 5'UTR with or without a disruption of its stable secondary structure. As described earlier, the two new plasmids, pBAD33- $(S-I R)-c l p Q^{+}$and pBAD33- $(R-I R)-c l p Q^{+}$, were constructed. In these constructs, the $(S-I R)-c l p Q^{+}$gene has replaced the nucleotides on the 5' end of UTR, with a $\Delta \mathrm{G}=-10.1 \mathrm{kal} / \mathrm{mol}$, that destabilized a stem-loop structure (Fig. 8A-a); in contrast, the pBAD33-(R-IR)-clp $Q^{+}$gene has replaced the nucleotides on the 5 ' end of UTR, with a lower $\Delta \mathrm{G}=-24.6 \mathrm{kal} / \mathrm{mol}$, that stabilized a stem-loop structure. AC3112 cells, which carry pBAD24-clp $Y^{+}$and pBAD33-(S$I R)-c l p Q^{+}$, show a higher $\beta \mathrm{Gal}$ activity, as compared to that of cells carrying pBAD24-clp $Y^{+}$and pBAD33-clpQ $Q^{+}$(Fig. 8B). In contrast, cells that carry pBAD24-clp $Y^{+}$and pBAD33$(R-I R)-c l p Q^{+}$show the decreased expression of cpsB::lacZ (Fig. 8B). AC3112, which carries pBAD33- $\Delta I R-c l p Q^{+}$and
pBAD24-clp $Y^{+}$, has higher $\beta$ Gal activity of the cpsB::lacZ expression as that of cells with pBAD33 and pBAD24 (Fig. 8B). In the northern blot analysis, the level of $(S-I R)-\operatorname{clp} Q^{+}$ message was much lower than that of the $\operatorname{clp} Q^{+}$and was more similar to that of the $\Delta I R-\operatorname{clp} Q^{+}$; in contrast, the message of $(R-I R)-c l p Q^{+}$was similar to that of the wild-type $\operatorname{clp} Q^{+}$(Fig. 8C).

\section{DISCUSSION}

Using a $\operatorname{clp} Q^{+}: \because l a c Z$, a gene fusion, the results presented here show that $\operatorname{llp} Q^{+}: \because \operatorname{lac} Z$ has similar $\beta \mathrm{Gal}$ activity in constructs containing either a long or a short region of the upstream sequence of the $\operatorname{clp} Q^{+} Y^{+}$promoter. We have shown that the further sequence upstream of the $\operatorname{clp} Q^{+} Y^{+}$promoter has no significant effects on its gene expression. Yet, as usual, a higher $\beta \mathrm{Gal}$ level was detected with the clp $Q^{+}:: l a c Z^{+}$transcriptional fusion as compared to the translational fusion, and it is accordingly due to a stronger SD region of the $\mathrm{LacZ}^{+}$itself in the transcriptional gene fusion [22].
(A) (a)

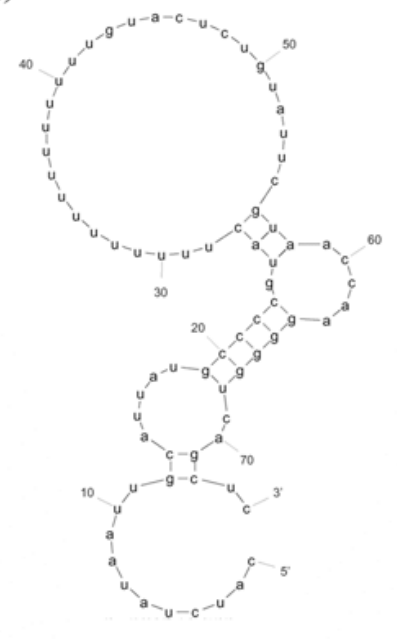

$\triangle \mathrm{G}=-10.1 \mathrm{kcal} / \mathrm{mol}$ (b)

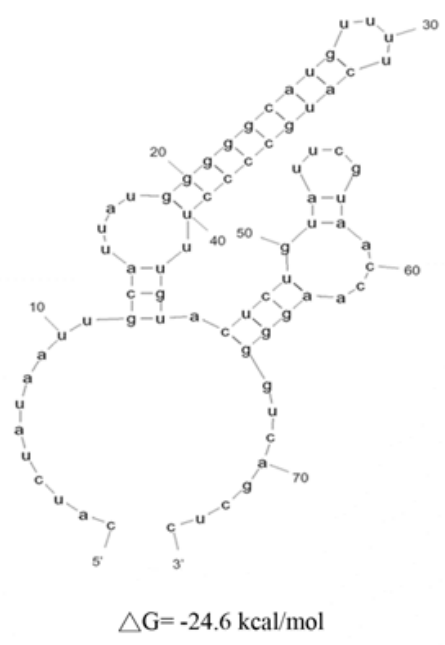

(C)

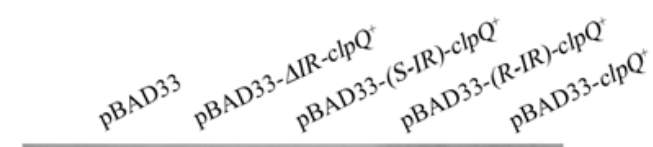

(B)

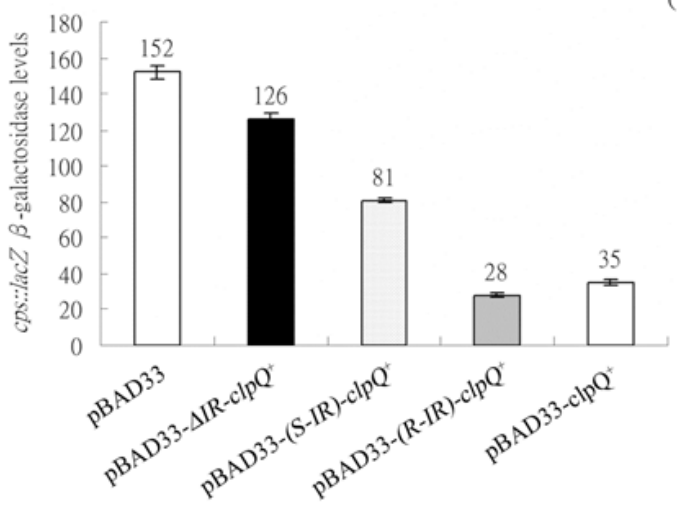

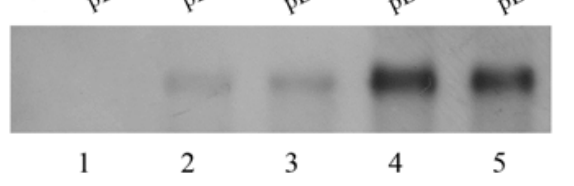

Fig. (8). (A) The secondary structures of 5'-UTR in (a) $(S-I R)-c l p Q^{+}$with $\Delta \mathrm{G}=-10.1 \mathrm{kcal} / \mathrm{mol}$ and $(\mathbf{b})(R-I R)-c l p Q^{+}$with $\Delta \mathrm{G}=-24.6$ $\mathrm{kcal} / \mathrm{mol}$. (B) The $\beta \mathrm{Gal}$ activities of $c p s B:: l a c Z$, in the presence of ClpY, the ClpQ was induced from $\mathrm{pBAD} 33-(S-I R)-c l p Q^{+}$or $\mathrm{pBAD} 33-(R$ $I R)-\operatorname{clp} Q^{+}$, as compared to the control pBAD33-clp $Q^{+}$and $\mathrm{pBAD} 33-\Delta I R-\operatorname{clp} Q^{+}$. (C) The mRNAs of $\operatorname{clp} Q^{+}$from the $\mathrm{pBAD} 33-(S-I R)-\operatorname{clp} Q^{+}$ and $\mathrm{pBAD} 33-(R-I R)-\operatorname{clp} Q^{+}$as compared to those from the $\mathrm{pBAD} 33-\operatorname{clp} Q^{+}$and $\mathrm{pBAD} 33-\Delta I R-\operatorname{clp} Q^{+}$. 
Coincidentally, $\operatorname{clp} Q^{+} Y^{+}$and $\operatorname{clp} Q^{+}:: \operatorname{lac} Z$ (op or pr fusion) genes have increased expression when the temperature is up-shifted from $30{ }^{\circ} \mathrm{C}$ to $42{ }^{\circ} \mathrm{C}$. Little of $\operatorname{clp} Q^{+} Y^{+}$or $\operatorname{clp} Q^{+}: \because l a c Z^{+}$mRNA was observed in the $r p o H$ mutant. In addition, a $\operatorname{clp} Q^{m l}: \because l a c Z^{+}$, with a $\mathrm{C}$ to $\mathrm{T}$ mutation in the $\mathrm{RpoH}-10$ consensus sequences, was shown to have decreased $\beta \mathrm{Gal}$ activity, independent of a functional $\mathrm{RpoH}$; there was also no heat shock induction in $\operatorname{clp} Q^{m l}: \because \operatorname{lacZ}$ (op or pr fusion). Using the transcriptional start site as a primer initiating site in the RT-PCR, the end-product for the transcripts of $\operatorname{clp} Q^{m l}:: l a c Z^{+}$, was less accumulated as compared to those of the wild-type $\operatorname{clp} Q^{+}: \because$ lac $Z^{+}$(data not shown). However, no signal was detected for the transcripts of both fusion genes, while using an annealing primer complementary to the nucleotides upstream of the transcriptional start site (data not shown). These results indirectly implied that both $\operatorname{clp} Q^{+}: \because l a c Z^{+}$and $\operatorname{clp} Q^{m l}: \because l a c Z^{+}$should have the identical transcriptional start site. In addition, we also made an additional mutation in the $\operatorname{clp} Q^{+} Y^{+}$promoter region at the possible -10 site for the RpoS binding [see in the (Fig. 1)], and this mutation has no effects on an activity of the $\operatorname{clp} Q^{+} Y^{+}$ promoter (data not shown). Therefore, we have experimentally shown that $\operatorname{clp} Q^{+} Y^{+}$gene expression is mediated by the RpoH factor.

The deletion of the IR or UTR in the $\Delta I R-\operatorname{clp} Q^{+}, \Delta L$ $\operatorname{clp} Q^{+}$and the $\operatorname{clp} Q^{m 2} \Delta 40: \because l a c Z$ gene fusion leads to decreased $\operatorname{clp} Q^{+}$mRNA. In addition, the mRNAs of $\triangle I R-\operatorname{clp} Q^{+}$ mutants, without a stem-loop region at the 5'-UTR, decayed much faster. However, no significant sequences were observed in the 5' UTR of the $\operatorname{clp} Q^{+} Y^{+}$messages acting as a signal for targeting by the RNase E degradosome (an AU rich or A/GAUU/AU) $[28,29]$ or the RNase III (A/UNAGA/ UG) [30]. We also found that a functional ClpQ is not affected by a higher temperature (data not shown); thus, there is no thermo-sensitive segment in the $\operatorname{clp} Q^{+}$message. However, while obliterated the IR in the ${ }^{\prime}$ ' UTR of $\operatorname{clp} Q^{+} Y^{+}$ mRNA but retained its stem-loop structure, a stable mRNA was present. In E. coli, it has been reported that the 5' stemloop structure stabilizes the mRNA of papA (pyelonephritisassociated pili gene) [31] and ompA (outer membrane protein) $[32,33]$ under physiological conditions, and it was later found that ompA is being regulated by the small micA RNA [34]. Currently, a model is emerging of small RNA sequences that are involved in gene regulation [35]. In some cases, an Hfq (a host factor for RNA phage $\mathrm{Q} \beta$ phage replication) [36], RNA-binding protein is also involved in it [35]. It stabilizes sRNAs against decay and also helps an association with their mRNA target [35]. However, no such effects were found for the $\operatorname{clp} Q^{+}:: l a c Z^{+}$fusion gene expression (our own data). Besides, in the wild bacterial genome, the 5' UTR was also found in the $\operatorname{clp} Q^{+} Y^{+}$mRNA transcripts mainly in the Enterobacteriaceae family. These bacteria all have the conserved sequences of the 5' UTR of $\operatorname{clp} Q^{+} Y^{+}$mRNA for a predicted secondary stem-loop structure. However, via the bioinformatics, the conservation of sequence of the small RNA is not sufficient for a searching of a regulation of the target gene; a more sophisticated algorithm is needed [37]. It is noteworthy that this is the first example in the ATPdependent proteases to demonstrate that the 5' stem-loop structure itself participates in the stability of its downstream mRNA. It is of interest to determine whether this stem-loop structure in the 5'UTR plays a role for its gene expression under certain physiological condition and also whether there is a regulation of $\operatorname{clp} Q^{+} Y^{+}$by the other regulatory proteins or via the small RNA.

\section{ACKNOWLEDGEMENTS}

We thank Dr. Hengge-Aronis, Dr. Ramos, Dr. Yura, and Dr. M. Kanemori, for bacterial strains. We thank Dr. R. F. Liu for technique supports. We also thank Dr. S. Gottesman for the comments. Thanks to Dr. B. Collins for a support. This work was supported by grants from the Department of Health (DOH89-TD-1068, DOH90-TD-1078, DOH-91-TD1082) and National Science Council (NSC93-2313-B-002077) of Taiwan, R.O.C.

$$
\begin{aligned}
& \text { ABBREVIATIONS } \\
& \text { UTR }=\text { Untranslated leader region } \\
& \text { op }=\text { Transcriptional } \\
& \text { pr }=\text { Translational } \\
& \text { RBS }=\text { Ribosome-binding site } \\
& \mathrm{wt} \quad=\text { Wild-type } \\
& \beta G a l=\beta \text {-galactosidase } \\
& \mathrm{nt} \quad=\text { Nucleotide(s) } \\
& \mathrm{bp} \quad=\text { Base pair(s) } \\
& \mathrm{kb} \quad=1000 \mathrm{bp} \\
& \mathrm{LB} \quad=\text { Luria-Bertani }
\end{aligned}
$$

\section{REFERENCES}

[1] Chuang SE, Burland V, Plunkett G, 3rd, Daniels DL, Blattner FR. Sequence analysis of four new heat-shock genes constituting the hslTS/ibpAB and hslVU operons in Escherichia coli. Gene 1993; 134: 1-6.

[2] Missiakas D, Schwager F, Betton JM, Georgopoulos C, Raina S. Identification and characterization of HsIV HsIU (ClpQ ClpY) proteins involved in overall proteolysis of misfolded proteins in Escherichia coli. EMBO J 1996; 15: 6899-909.

[3] Rohrwild M, Coux O, Huang HC, et al. HslV-HslU: A novel ATPdependent protease complex in Escherichia coli related to the eukaryotic proteasome. Proc Natl Acad Sci USA 1996; 93: 5808-13.

[4] Kanemori M, Yanagi H, Yura T. Marked instability of the sig$\mathrm{ma}(32)$ heat shock transcription factor at high temperature. Implications for heat shock regulation. J Biol Chem 1999; 274: 22002-7.

[5] Khattar MM. Overexpression of the hslVU operon suppresses SOS-mediated inhibition of cell division in Escherichia coli. FEBS Lett 1997; 414: 402-04.

[6] Seong IS, Oh JY, Yoo SJ, Seol JH, Chung CH. ATP-dependent degradation of SulA, a cell division inhibitor, by the HslVU protease in Escherichia coli. FEBS Lett 1999; 456: 211-4.

[7] Seong IS, Oh JY, Lee JW, Tanaka K, Chung CH. The HsiU ATPase acts as a molecular chaperone in prevention of aggregation of SulA, an inhibitor of cell division in Escherichia coli. FEBS Lett 2000; 477: 224-9.

[8] Smith CK, Baker TA, Sauer RT. Lon and Clp family proteases and chaperones share homologous substrate-recognition domains. Proc Natl Acad Sci USA 1999; 96: 6678-82.

[9] Wu W-F, Zhou YN, Gottesman S. Redundant in vivo proteolytic activities of Escherichia coli Lon and the ClpYQ (HslUV) Protease. J Bacteriol 1999; 181: 3681-7.

[10] Kuo M-S, Chen K-P, Wu WF. Regulation of ResA by the ClpYQ (HslUV) protease in Escherichia coli. Microbiology (Reading, England) 2004; 150: 437-46. 
[11] Munavar H, Zhou Y, Gottesman S. Analysis of the Escherichia coli Alp phenotype: heat shock induction in $s s r A$ mutants. J Bacteriol 2005; 187: 4739-51.

[12] Lee Y-Y, Chang C-F, Kuo C-L, et al. Subunit oligomerization and substrate recognition of the Escherichia coli ClpYQ (HslUV) protease implicated by in vivo protein-protein interactions in the yeast two-hybrid system. J Bacteriol 2003; 185: 2393-401.

[13] Lau-Wong IC, Locke T, Ellison MJ, Raivio TL, Frost LS. Activation of the Cpx regulon destabilizes the F plasmid transfer activator, TraJ, via the HslVU protease in Escherichia coli. Mol Microbiol 2008; 67: 516-27.

[14] Wu WF, Yang C-S, Lien H-Y, Hsieh F-C, Chang C.-Y. In: Kutejova E, Ed. ATP-dependent protease; HslUV (ClpYQ), an ATPdependent protease with unique characteristics 2008; pp. 115-43.

[15] Gottesman S. Regulation by proteolysis. In, Escherichia coli and Salmonella typhimurium: cellular and molecular biology. Washington, D.C. American Society for Microbiology 1987; pp. 1308-12.

[16] Bukau B. Regulation of the Escherichia coli heat shock response. Mol Microbiol 1993; 9: 671-80.

[17] Yura T, Nagai H, Mori H. Regulation of the heat shock response in bacteria. Annu Rev Microbiol 1993; 47: 321-50.

[18] Casadaban M. Transposition and fusion of the lac genes to selected promoters in Escherichia coli using bacteriophage lambda and Mu. J Mol Biol 1976; 104: 541-55.

[19] Yano R, Imai M, Yura T. The use of operon fusions in studies of the heat shock response: effects of altered sigma32 on heat-shock promoter function in Escherichia coli. Mol Gen Genet 1987; 207: 24-8.

[20] Lange R, Hengge-Aronis R. Identification of a central regulator of stationary-phase gene expression in Escherichia coli. Mol Microbiol 1991; 5: 49-59.

[21] Marques S, Manzanera M, Gonzalez-Perez MM, Gallegos M-T, Ramos JL. The XylS-dependent Pm promoter is transcribed in vivo by RNA polymerase with $\sigma^{32}$ or $\sigma^{38}$ depending on the growth phase. Mol Microbiol 1999; 31: 1105-13.

[22] Simons RW, Houman F, Kleckner N. Improved single and multicopy lac-based cloning vectors for protein and operon fusions. Gene 1987; 53: 85-96.

[23] Silhavy TJ, Berman ML, Enquist LW. In, Experiments with gene fusions. Cold Spring Harbor, N.Y: Cold Spring Harbor Laboratory 1984.
[24] Miller JH. A short course in bacterial genetics. Cold Spring Harbor, NY: Cold Spring Harbor laboratory 1992.

[25] Chung CT, Niemela SL, Miller RH. One-step preparation of competent Escherichia coli: transformation and storage of bacterial cells in the same solution. Proc Natl Acad Sci, USA 1989; 86: 2172-5.

[26] Guzman L-M, Belin D, Carson MJ, Beckwith J. Tight regulation, modulation, and high-level expression by vectors containing the arabinose $\mathrm{P}_{\mathrm{BAD}}$ promoter. J Bacteriol 1995; 177: 4121-30.

[27] Zuker M. Mfold web server for nucleic acid folding and hybridization prediction. Nucleic Acids Res 2003; 31: 3406-15.

[28] McDowall KJ, Lin-Chao S, Cohen SN. A+U content rather than a particular nucleotide order determines the specificity of RNase E cleavage. J Biol Chem 1994; 269: 10790-6.

[29] Ehretsmann CP, Carpousis AJ, Krisch HM. Specificity of Escherichia coli endoribonuclease RNase E: in vivo and in vitro analysis of mutants in a bacteriophage T4 mRNA processing site. Genes Dev 1992; 6: 149-59.

[30] Krinke L, Wulff DL. The cleavage specificity of RNase III. Nucleic Acids Res 1990; 18: 4809-15.

[31] Bricker AL, Belasco JG. Importance of a 5' stem-loop for longevity of papA mRNA in Escherichia coli. J Bacteriol 1999; 181: 3587590.

[32] Emory SA, Belasco JG. The ompA 5' untranslated RNA segment functions in Escherichia coli as a growth-rate-regulated mRNA stabilizer whose activity is unrelated to translational efficiency. J Bacteriol 1990; 172: 4472-81.

[33] Emory SA, Bouvet P, Belasco JG. A 5'-terminal stem-loop structure can stabilize mRNA in Escherichia coli. Genes Dev 1992; 6: $135-48$.

[34] Udekwu KI, Darfeuille F, Vogel J, Reimegård J, Holmqvist E, Wagner EG. Hfq-dependent regulation of OmpA synthesis is mediated by an antisense RNA. Genes Dev 2005; 19: 2355-66.

[35] Gottesman S, McCullen CA, Guillier M, et al. Small RNA regulators and the bacterial response to stress. Cold Spring Harb Symp Quant Biol 2006; 71: 1-11.

[36] Franze de Fernandez MT, Hayward WS, August JT. Bacterial proteins required for replication of phage $Q$ ribonucleic acid. Purification and properties of host factor I, a ribonucleic acid-binding protein. J Biol Chem 1972; 247: 824-31.

[37] Vogel J, Wagner EGH. Target identification of small noncoding RNAs in bacteria. Curr Opin Microbiol 2007; 10: 262-70.

(C) Lien et al.; Licensee Bentham Open.

This is an open access article licensed under the terms of the Creative Commons Attribution Non-Commercial License (http://creativecommons.org/licenses/by-nc/3.0/) which permits unrestricted, non-commercial use, distribution and reproduction in any medium, provided the work is properly cited. 